\title{
COUNTERING DIGITAL CRIME IN THE ECONOMY AND ITS LEGAL SUPPORT
}

\section{NGUYEN HUY BINH}

PhD in Law, Deputy head of the criminal police Department,People's Police Academy,

\author{
Hanoi, Vietnam
}

\begin{abstract}
IT-oriented crime in the economy and business is a little-studied social and legal phenomenon. Without a systemic approach, it cannot be fully explored, even on a national scale. The results of the system-legal analysis of the current state and trends of economic crimes in the context of digital transformation in Vietnam and other countries close to the economy are visionary in the work. On the basis of the analysis, recommendations have been made to increase the effectiveness of the fight against high-tech economic crimes. Among other things, improving forensics to improve the effectiveness and sustainability of the fight against such crimes. The system analysis made it possible to draw a number of conclusions, in particular, on the impossibility of fully identifying and personalizing economic relations. Is important the following principle of the need to model and predict reverse links, as well as to create and use appropriate infrastructure, including electronic support of judicial evidence. Systemically justified proposals for improving measures to prevent and counter economic crime in the digital economy have been proposed. The need for special solutions and legal categories is justified. It's also proposed to adapt a number of existing economic and legal concepts to effectively counter high-tech and mobile criminal groups. The experience of Russia, Vietnam, South-East Asia has been used. Consideration has been given to the need for preventive capacity in Viet Nam's criminal legislation.

KEYWORDS: system Analysis, Economic Crime, Digital Economy, Law, Digital Crimes \& Counteraction.
\end{abstract}

Received: Jun 01, 2020; Accepted: Jun 20, 2020; Published: Jun 30, 2020; PaperId.: IJMPERDJUN2020233

\section{INTRODUCTION}

The law and jurisprudence of a digital society should be based on reliable and relevant information sufficient to counter crime and manage criminal policy processes and systems, as well as to combat crime. Especially, with digital. This makes it possible to make decisions quickly, to ensure the digital and economic security of the individual, society and the State. Therefore, it's important to implement a systemically planned response to digital crimes in the economy, ensuring the predictability of damage and reaction of the legal system.

It's difficult to clearly define the set and mutual nature of crimes related to the use of the automated and intellectual tools of criminals. They are continuously evolving and transforming, as are the methods of crime. They are difficult to identify, predict and classify. The lateness of crimes and their "species diversity" hinders.

The state's criminal legal response lags behind in the mobility of economic crime in digital society. In addition to the traditional unauthorized computer penetration of the system by means of hacking or virus, criminals began to use crypto-encryption, intelligent password selection (tracking) and other latest methods.

In Vietnam, economic crime was widely interpreted until 1985, but there was no category of "economic crime" in criminal law until 2000. Therefore, the state has introduced many normative acts ensuring the fight against 
economic violations, for example, on attempt on grain speculation, for currency speculation, counterfeiting and others [1].

In the creation of a digital economy and effective criminal legislation, the Vietnamese State is interested in protecting its economic stability and providing it with a developed IT infrastructure, using the example of the developed countries of South-East Asia. But there was no systemic study in the complex while providing these two important tasks. Most acts and regulations regulate only individual crimes.

The strategic approach had just begun to develop, which had first been facilitated by the Ordinance on the Punishment of Attacks on Socialist Property. It relates to an offence, directly or indirectly, which is actually or potentially harmful to objects of national economic purpose. Secondly, the Laws of Financial Management and Economic Efficiency are involved. Special attention in economic security and improvement of Vietnamese life was paid to the fight against production of counterfeit goods, illegal entrepreneurship, evasion of taxes and laws, smuggling and speculation, sale of prohibited goods, etc.

The legal terminology included the terms "infringement of economic management (ownership)", "corruption", etc. The Criminal Code establishes the categories of "economic management procedure" (Cap. XVI), "official crime" (Cap. XXI), "crime against property" (Cap. XIV), etc.

It's time to update and add categories. In particular, ensuring effective opposition to high-tech and disruptive measures, as well as economic crimes in various spheres.

Laws and criminal laws in the field of legal support for the security of economic relations in the digital society in Viet Nam are still imperfect. Research on these issues should be supported, not only on individual issues, but in a systematic manner. Only a systematic approach will help to solve this problem effectively and without unnecessary investments. This work focuses on this current issue.

\section{THEORETICAL FRAMEWORK}

The term "digital economy" was first used by Don Tapscott in 1994, then popularized by Nicholas Negroponte in 1995. Until there is a systemic, broad understanding of this category, narrow interpretations are used - network economics, Internet economy, post-industrial economy, creative economy, etc.

Non-traditional property resources and rights can be actively used in legal economic turnover in the digital economy. For example, Internet sites, crypto and electronic money, online stores and others [2]. They are more dangerous than "non-computer" crimes because they are capable of causing damage latently, with a wide range of coverage (from private to public interest).

In Viet Nam's legal field, it's clear to the entire legal community that only national information systems, technologies and intellectual-legal solutions will preserve digital sovereignty and economic security. Especially solutions that help to quickly and fully reflect on the criminal innovations of digital economic relations and their risks.

Digital transformations in the economy, fundamental changes in classical models of economic management and business conduct lead to weakening of the management resource of the state [3]. 
On the adopted Digital Economy Development Index (share of GDP), Vietnam is far from leaders (UK, about 13\%; South Korea, more than 8\%; China, about 7\%), like Russia (more than 3\%). But digital development is given great attention, as in other developing countries [4].

The digital economy in a broad sense is an economy based on effective IT infrastructure and socio-cultural and technological capabilities of the consumer, business and the state [5]. The development of the digital economy is inevitably accompanied by an increase in crime on business-oriented Internet platforms [6].

Cybercrime threatens the entire life support infrastructure of the state [7] and is latent, threatening social structures [8]. Threats increase legal and IT illiteracy, as well as the inertia of victims and the nihilism of intruders.

The laws explicitly provide for criminalizing features, their extension to digital relations and information and telecommunication networks (such as for insiders), or state the presumption of such a possibility (such as in the case of a rule). This is also used by criminals, for example, the data of the executive cases of the site of court officers of open access can be used for criminal purposes. Even modern, progressive web marketing techniques, such as neuromarketing, are used for fraudulent purposes [9].

Often are not enough IT competent investigators and investigators, their unsatisfactory instrumental and methodological training. Much of the valuable evidentiary information may not be extracted, processed or used in a criminal case. The lack of a systematic and institutional approach to the analysis of digital economic crime affects the sustainability and effectiveness of law enforcement forces. For example, according to the Ministry of Internal Affairs of the Russian Federation, 2,382 crimes were recorded in 2015, but 235 people were convicted; In 2016 - already 2,197 people. At the same time, only $72 \%$ of investigators estimate their IT-level as "at the average user" [10].

The leading motive (98\%) for committing a crime in the economy is enrichment, as evidenced by the results of surveys [11]. In the digital economy, other motives are possible, in particular revenge after dismissal, psychological incompatibility with staff, industrial espionage or insider with "moral satisfaction". Corporate and partnership, client interests and objectivity of investigation, final model of prosecution (committed crime), legal assessment and qualification of the act suffer [12].

\section{METHODOLOGY}

In the structure of recorded crimes of economic orientation, financial and credit cases usually prevail. The criminal risks of IT-supported crimes are high here, and the financial and credit sphere itself is more vulnerable. Analysis of cases in Vietnamese jurisdiction shows that the dynamics and rate of commission of crimes (both traditional and recent phishing, carding, etc.) directly correlate with the level of IT-security of participants in market relations [13]. But there are three main problems:

- IT security depends directly on investments (FireWall, Big Data, etc.) and small and even medium-sized businesses;

- it's difficult to identify the offender, to prosecute him and to denounce the public, which contributes to the high latency of such crimes; 
- group crime in digital transactions is growing, which generates new and new forms, such as criminal macro networks, in which both visitors to closed online communities of national networks and international structures participate [14].

The structures of the internal affairs agencies of Viet Nam responsible for ensuring economic security note the increasing complexity of the qualification of acts in the initiation of criminal proceedings, their labour intensity and resource intensity in the conduct of expert examinations. The impossibility of complete identification and personification of economic relations also affects. Often limited to establishing individual signs of crime rather than the entire system picture. Therefore, the legal assessment can be clarified iteratively during the investigation.

Economic processes often move into criminal law and criminal procedure processes. A critical analysis - a "cynical" expert study or an assessment of the data on the situation under consideration - may be needed. The purpose of such analysis is not only to assess, but to understand, reduce the information uncertainty of the situation.

\section{RESULTS AND DISCUSSIONS}

As the national and global digital economy develops, the issue of digital security of the economy and business is being updated. It was important to carry out a system analysis-synthesis of the key subsystems and processes of this phenomenon, this system. As a result of the analysis done in the work, it is probably possible to talk about the digital economy as a new evolutionary economy. In law and even in economics, the category "digital economy" does not yet have clear boundaries. There is no clear system of key concepts and legal rules, which poses additional risks to the security of digital economy systems.

The economic security of the State is multidimensional and multi-critical. Digital transformation improves the infrastructure of the economy, the system of security management, priorities and protection, as well as the assessment of damage from economic crimes.

The purpose of ensuring the economic security of a particular business is to improve commercial activity, IT support and protection of the business, ensuring its competitiveness. There is a need for business-worthy protection against espionage, insiders and attacks on copyright and technological, information-logical products (goods and services). External threats - organized crime, collusion of competitors. Internal - actions of personnel, employees (by collusion or negligence), violation of corporate security policy. All this leads to economic or reputational damage.

Impacts include financial reports, marketing and audit data, pricing policies and business plans, partner programs, technology and organizational documentation. Ways of acquiring such information are:

- legitimate methods of analysis and collection of data of exhibitions, fairs, etc.;

- $\quad$ studying competitive opportunities and policies of the competitor;

- illegal - bribery, sending agents, theft, secret control, technical implementation in the network, software interception, etc.

To protect economic digital communications, it's necessary to audit and assess risks and potential threats, then classify them by importance and impact on damage, as well as the evolution of the economic system. The goal is to identify threat channels [15]. 
Interactions are strongly influenced by structuring, which is usually network or hierarchical. They are most relevant to the digital economy, its integration processes and reflect the interaction of key economic agents that are well modeled by neuro-systems [16]. Structural complexity of the system, connectivity of network elements can be taken as an indicator of safety of structural links. Connections are efficiently formed and modeled, integrated, as noted above, by many-agency models. Networking is the foundation of integration in the fight for security [17].

We refer to technical and technological methods of supporting the solution of problems:

- firewalls of the latest generations and configurations;

- data filtering and distribution means according to the security policy;

- code access with distinction of access rights of users, administrators;

- blocking of corporate information resources;

- neuro-audit and neuro-monitoring of user activity;

- crypto-encryption/data decryption, etc.

In the forensic aspect, economic crimes are not only latent and secretive, based on IT, but also highly profitable [18]. Table 1 shows comparative statistics, for example, on attacks of user maps in Runet. There were 766728 attempts to access bank accounts online in 2019 .

Table 1: Dynamics of the number of Attacks on Plastic Card Holders in Runet (Author, Data of Statistical Reports of Kaspersky Lab by years)

\begin{tabular}{|l|c|c|}
\hline & Explicit Attacks & Latent Attacks \\
\hline 01.01 .2014 & 1927120 & 596741 \\
\hline 01.04 .2014 & 1864212 & 697127 \\
\hline 01.08 .2014 & 1526879 & 780954 \\
\hline 01.12 .2014 & 1727120 & 648874 \\
\hline 01.01 .2015 & 1624948 & 824987 \\
\hline 01.04 .2015 & 1650684 & 648048 \\
\hline 01.08 .2015 & 1727546 & 542308 \\
\hline 01.12 .2015 & 1834908 & 423574 \\
\hline 01.01 .2016 & 1896134 & 398410 \\
\hline 01.04 .2016 & 2306348 & 512064 \\
\hline 01.08 .2016 & 1790648 & 374310 \\
\hline 01.12 .2016 & 2184064 & 390476 \\
\hline 01.01 .2017 & 1746480 & 318730 \\
\hline 01.04 .2017 & 1672064 & 297530 \\
\hline 01.08 .2017 & 1644601 & 283403 \\
\hline 01.12 .2017 & 1780419 & 310371 \\
\hline 01.01 .2018 & 1659450 & 249621 \\
\hline 01.04 .2018 & 1965772 & 359349 \\
\hline & & \\
\hline
\end{tabular}


Therefore, their identification and investigation will also require the use of appropriate infrastructure, even electronic evidence and the accompanying judicial review. This security is still lagging behind.

The evolution of the digital economy is particularly relevant for the analysis of the corruption component of transactions and the identification of the counterparty, as well as the integration of the efforts of countries, the synthesis and systematic analysis of their experience. It's important to develop methods of investigation of economic IT-oriented crimes [19].

Statistical support for forecasting and monitoring the real situation of digital economic crimes is also needed. This will allow identification of both simple correlation connections and more complex mathematical models. They are necessary, for training, to learn how to identify corruption ties. For example, Russian forensics lacks not only its own technologies and software products (more than $80 \%$ - foreign), but also systematization [20]. This situation is also common in Viet Nam.

The commonality of tasks and solutions to counter crimes in the field of digital economy in Vietnam and Russia allows us to conclude: it's necessary to focus on system analysis [21], updating and legal framework and recommendation instructions [22].

It's important to have relevant system security indicators. To solve this complex problem, we propose to involve Data Mining, Big Data, etc., as well as a fuzzy and neural network approach. They will allow assessing the safety measure of the system taking into account hidden (latent) factors and synergistic effects of structural digital transformations.

Like any measure in the system sense, a security measure is a non-negative function defined in the space of possible security scenarios (solutions). It satisfies the conditions: it's little sensitive to changes in the economic situation, resistant to them and behavior (scenario) of the offender, etc.

Sustainability is a balanced development, taking into account the environment, digital changes, their pace and structure. The trajectory of digital development should, reducing social inequality and risks, strengthen digital interactions without giving in to possible economic manipulation [23].

\section{CONCLUSIONS}

Digital transformation in the economy leads to an increase in crimes of an economic nature, more developed in technological and digital terms. Predominantly, economic crime is characteristic in all countries of its activity, speed and mobility, as well as the many platforms and tools that are activated for crime. Such crime is a threat to the economy of the State and to society.

It's necessary to intensify criminal legal measures to combat economic offences on a digital basis, as a socially dangerous phenomenon. As a result of the system analysis carried out, we consider it necessary to introduce new and clarify existing legal categories of digital crime. Situational models (algorithms and programs) should also be developed to model risks and damage from digital economic crimes, including transnational ones.

In order to explore, study the completeness and depth of digital relationships in the economy, a systemic approach is needed. To evaluate their effectiveness, relevant techniques and models are needed. The process of evaluating and selecting a security management strategy (security policy) itself requires system analysis and serious study, but is always effective if the entire management lifecycle is supported by resources and management. 


\section{REFERENCES}

1. Konovalov, I.A., Nguyen, V.N. (2017) Concept of economic crimes in the legislation of Vietnam // Journal of the Moscow State Regional University. Series: Jurisprudence, N4, pp.156-162. DOI: 10.18384/2310-6794-2017-4-156-162.

2. Leukfeldt, E.R. (2015) Organised cybercrime and social opportunity structures: a proposal for future research directions // The European Review of Organized Crime. №2. pp.91-103.

3. Necrasov, V.N. (2017) Topical issues of criminal law protection of information activity in Russia // Topical issues of Russian law. №7. - pp.108-114.

4. Betigeri, AMRUTA S., and M. A. N. A. S. I. Dixit. "Modification In Human Face Image For Personal Identification." International Journal of Applied Engineering Research and Development 4.2 (2014): 13-22.

5. Sukhodolov, A.P., Kolpakov, L.A., Spasennikov, B.A. (2017) Problems of combating crime in the field of digital economy // All-Russian criminological journal. 2017. T.11, No. 2. pp.258-267. DOI 10.17150/2500-4255.2017.11(2).258-267.

6. Strelkova, I.A. (2018) Digital Economy: New Opportunities and Threats for the Development of the World Economy // Economics. Taxes. Right, No.2, pp.18-26. DOI: 10.26794/1999-849x-2018-11-2-18-26.

7. Lakshmi, A. K. "The selfie culture: Narcissism or counter hegemony." Journal of Communication and media Studies (2015). Journal of Communication and Media Studies (JCMS) 5. 1, Jun 2015, 1-4

8. Boes, S., Leukfeldt, E.R. (2016) Fighting cybercrime: joint effort // Ciber-Physical Security: Protecting Critical Infrastructure at the State and Local Level. -Cincinnati: Springer. - pp.185-205.

9. MAHAJANI1, R. I. N. I., and DHEERENDRA SINGH. "STEP BY STEP SECURING CLOUD ENVIRONMENT." International Journal of General Engineering and Technology (IJGET) 6.4, Jun-Jul 2017; 47-54

10. Broadhurst, R., Grabosky, P., Alazab, M., Chon S. (2014) Organizations and cybercrime: an analysis of the nature of groups engaged in cybercrime // International Journal of Cyber Criminology. Vol.8, iss.1. -pp.1-20.

11. Hajli, N., Featherman, M.S. (2017) Social commerce and new development in e-commerce technologies // International Journal of Information Management. №37. - pp.177-178.

12. Menthe, D. (1998) Jurisdiction in cyberspace: a theory of international spaces // Michigan Telecommunications and Technology Law Review. Vol.4, iss.1. -103 p.

13. MUDASSIR KHAN, MOHAMMAD AYYOOB. "Cyber Security and Ethics on Social Media." Journal of Modern Developments in Applied Engineering \& Technology Research 1.2 (2017): 51-58.

14. Shevchenko, E.S. (2015) Current problems of cybercrime investigation // Forensic expert. N3. -pp.29-30.

15. Truntsevsky, Yu.V. (2016) State and trends of crime in the Russian Federation and forecasts of its development // Russian Justice No.8. - pp.29-31.

16. Russkevich, E.A. (2017) Criminal Law and Informatization // Journal of Russian Law. №8. -pp.73-80.

17. Uskov, V.S. (2020) Scientific and Technological Development of the Russian Economy in the Transition to a New Technological Order. Economic and Social Changes: Facts, Trends, Forecast, vol.13, N1, pp.70-86. DOI: 10.15838/ esc.2020.1.67.4

18. Viano, C. (2017) Cybercrime, organized crime, and societal responses: international approaches / C. Viano. - Springer International Publishing, 2017. 
19. Maltseva, A.P., Loskarev, A.V. (2019) Impact of the digital economy on cybercrime // International Journal of Humanities and Natural Sciences, vol.10-2(37), pp.118-120. DOI: 10.24411/2500-1000-2019-11664.

20. Gribkov, E.I., Yekhlakov, Yu.P. (2020) Neural network model for user request analysis during software operations and maintenance phase. Business Informatics, vol.14, N1, pp.7-18. DOI: 10.17323/2587-814X.2020.1.7.18

21. Rossoshanskaya, E.A. (2019) Integrated agent-based model of labor potential reproduction of a municipal formation. Economic and Social Changes: Facts, Trends, Forecast, vol.12, N1, pp.124-137. DOI: 10.15838/esc.2019.1.61.7

22. Wall, D. (2005) Cybercrime as a conduit for criminal activity // Information, Technology and the Criminal Justice System. Beverly Hills CA: Sage Publications.

23. Shatalov, A.S. (2008) Development of methodological bases for investigation of crimes committed with the help of computer and network technologies: problems, prospects and trends // Journal of the Siberian Law Institute of the Ministry of Internal Affairs of the Russian Federation. №3(32), pp.10-15.

24. Falcon, V. Yu. (2017) Crisis of domestic forensics: monograph/V. Yu. Falcon. -Krasnodar. -332 p.

25. Kaziev, V.M., Kazieva, B.V., Kaziev, K.V. (2017) Foundations of legal informatics and informatization of legal systems, 2nd ed. -M.: INFRA-M, -336 p. ISBN-online: 978-5-16-104376-9. http://znanium.com/catalog/product/545154

26. Recommendation of the Council on Digital Security Risk Management for Economic and Social Prosperity. 17 September 2015 [Electronic resource]. Retrived from: http://www.oecd.org/sti/ieconomy/digital-security-riskmanagement.pdf.

27. Yuzhanin, M.A. (2020) The specifics of manipulative influence in contemporary social interactions and communications // Amazonia Investiga, vol.9 (26), pp.125-133. https://doi.org/10.34069/AI/2020.26.02.14.W 